\title{
Research Article: Constraints in adoption of mobile agro advisories by the farmers
}

\section{PRABHA AND R. ARUNACHALAM}

Article Chronicle :

Received :

19.07.2017;

Accepted :

03.08.2017

KeY Words:

Mobile agro advisory, Constraints, Suggestions

Author for correspondence :

\section{R. ARUNACHALAM}

Department of Agricultural Extension, Tamil Nadu Agricultural University, COIMBATORE (T.N.) INDIA

Email : dr.r.arunachalam @ gmail.com

See end of the article for authors' affiliations
SUMMARY : Agriculture is a back bone of Indian economy. Indian agricultural growth is hindered by low productivity, shrinking agricultural land base, urbanization, diversification in production and consumption bases, poor market linkages and other factors. Extensive use of modern information technologies need to be promoted at farm level for the transfer of technologies in a cost effective manner. Now-a-days mobile phone is anemerging tool to solve current problem inagriculture. Mobile agro advisory serviceson pest and disease management, nutrient management, intercultural operations, irrigation management, harvesting practices, weather information, market price information attracts huge volume of agriculturists. Even then farmers take a lot of constraints in the adoption of the recommended mobile advisories. Hence a study was conductedin Coimbatore district of Tamil Nadu with a sample of 200 farmers subscribing the SMS based agro advisories. The study revealed that most of the respondents $(84.50 \%)$ stated that they have not received any information pertinent to local crops, followed by about seventy per cent $(71.00 \%)$ have expressed their concern over the non receipt of messages on agricultural loans and government subsidies and about half of the respondents $(52.50$ $\%)$ stated that there were no messages related with soil and water testing. Most of the farmers $(79.00 \%)$ suggested to send the messages in local languages, a majority of the respondents $(65.50 \%)$ suggested to increase the frequency of the SMS advisories and about little less than half of the respondents $(46.50 \%)$ suggested to include picture and voice advisories.

How to cite this article : Prabha, D. and Arunachalam, R. (2017). Constraints in adoption of mobile agro advisories by the farmers. Agric. Update, 12(TECHSEAR-7) : 1782-1785; DOI: 10.15740/HAS/AU/ 12.TECHSEAR(7)2017/1782-1785. 